\title{
症例報告
}

\author{
特異な左室内隔壁を伴う左室二腔症 2 歳児に対する手術経験 \\ 野村 耕司 ${ }^{1)}$, 阿部 貴行 $^{1)}$, 成瀬 瞳 ${ }^{1)}$, 河内 文江 ${ }^{2)}$, 森 环磨 ${ }^{2)}$, 細谷 通靖 ${ }^{2)}$, \\ 菅本 健司 ${ }^{2)}$, 菱谷 隆 ${ }^{2)}$, 小川 潔 ${ }^{2)}$, 星野 健司 ${ }^{2)}$ \\ 1) 埼玉県立小児医療センター心臟血管外科 \\ 2) 埼玉県立小児医療センター循環器科
}

\section{Double-chambered Left Ventricle Associated with an Unusual Interventricular Wall: A Case Report}

\author{
Koji Nomura ${ }^{1)}$, Takayuki Abe ${ }^{1)}$, Hitomi Naruse ${ }^{1)}$, Fumie Kawachi' ${ }^{2)}$, Takuma Mori²), \\ Michiyasu Hosoya ${ }^{2)}$, Kenji Sugamoto ${ }^{2)}$, Takashi Hishitani²), Kiyoshi Ogawa' ${ }^{2)}$, and Kenji Hoshino ${ }^{2)}$ \\ 1) Department of Cardiovascular Surgery, Saitama Children's Medical Center, Saitama, Japan \\ 2) Department of Cardiology, Saitama Children's Medical Center, Saitama, Japan
}

\begin{abstract}
We report a very unusual case of a double-chambered left ventricle. A muscular partition, in the left ventricle, associated with a double-chambered left ventricle, was discovered in a boy aged 14 months. No cardiac structural abnormality had been detected previously. At the age of two years, and weight of $11 \mathrm{~kg}$, he was admitted to our medical center because of a systemic convulsion. Further diagnosis was made, considering brain infarction because of a left ventricular thrombus. Preoperative echocardiography showed severely depressed function of the apical chamber of the left ventricle with an embedded thrombus. The patient required an urgent thrombectomy concomitant with partial resection of the muscular partition wall between the apical and outlet chambers. Complete resection of the partition would have led to mitral valve dysfunction because of its continuity with the mitral papillary muscle. Postoperatively, the patient has been doing well with neither thrombus formation nor cardiac dysfunction.
\end{abstract}

Keywords: double-chambered left ventricle, partition, mitral valve, papillary muscle, thrombus

胎児期，および出生直後の心エコーではともに構造異常を認めなかった左心室腔内に，生後 1 歳 2 ケ月 時に隔壁構造を指摘された。隔壁により二腔化された左室内心尖腔（副腔）に血栓を生じるとともに 急速な副腔の収縮機能低下をきたした 2 歳男児に対して緊急手術にて血栓除去および隔壁部分切除術 を行った. 僧帽弁乳頭筋が付着している隔壁部分は温存した. 術直後から副腔機能は改善し, 血栓再 発や僧帽弁逆流は見られていない, 異常隔壁の発生・発達に極めて特異な経過をとった, 左室二腔症 の手術例を報告する.

\section{はじめに}

左室二腔症はその成因や形態的特徵から左室副腔 (accessory chamber), 左室㮩室 (diverticulum), 左 室緻密化障害 (non-compaction), 左室瘤 (aneurysm)
などとともに左室が二腔化された病態の総称である. 先天的な成因によるものとして，遺伝的変化や胎生期 変化による左室㕰室や緻密化障害が挙げられ ${ }^{1,2)}$, ま た後天的成因として虚血や変性による左室瘤が挙げら れる ${ }^{1)}$. 近年, 胎児心エコーの普及とともに先天性心

2015 年 8 月 6 日受付, 2015 年 10 月 13 日受理

著者連絡先：戸339-8551 埼玉県さいたま市岩柣区大字馬込 2100 番地 埼玉県立小児医療センター心蔵血管外科 野村耕司 doi: $10.9794 /$ jspccs.32.38 
疾患の出生前診断技術が向上し, 胎児期治療を含めた 生後早期治療介入が可能となり周産期医療は飛躍的 進歩を遂げた。こうした背景から心臓病の発現時期や 形態の系時的変化を出生前に特定し観察できるように なったが，これまで左室二腔症に関する胎生期も含め た発症時期や形態変化についての報告はない.

今回我々は胎生期や生直後には異常を認めず, 乳児 期以降に発達したと考えられる隔壁構造によって左室 二腔化を来した症例を経験した. 左室隔壁の発生時期 や機序が明らかではなく, 成因の特定が困難な左室二 腔症の 2 歳児に対して隔壁部分切除術を施行し, 臨床 症状と心機能の改善が得られた症例を経験したので報 告する.

\section{症例}

患児：2 歳男児 $11 \mathrm{~kg}$

主訴: 右不全片麻痺, 病攣発作

家族歴：特記すべきことなし

現病歴：妊娠経過中, 胎児心エコーにて不整脈（心室 性期外収縮）を指摘されていたが形態異常はなく在 胎 38 周 2 日 $3,018 \mathrm{~g}$ 正常分娩にて出生した. 出生時 心エコーでも卵円孔開存以外に構造異常は見られず, 8 ケ月時のホルター心電図にて 4,700 回／日の心室性 期外収縮を認めたが単発であり無投薬で経過観察され ていた. 1 歳 2 ケ月心エコーにて左室心尖部に異常筋 束を認めアスピリン内服を開始した. 1 歳 6 ケ月時の 心臓カテーテル検査で筋性隔壁によって二腔化された 左室心尖腔と流出路腔との間には圧較差は見られず,
両腔の拡張末期容積は正常比率で，心尖腔 $49 \%$, 流 出路腔 $49 \%$, 左室拡張終期圧 $9 \mathrm{mmHg}$, 左室拡張末 期容積正常比 $98 \%$ であった. 1 歳 9 ケ月時心筋シンチ グラフィーにて心尖部血流低下を認めたため, カロベ ジロール内服を開始し経過観察していたところ，1歳 11 ケ月時に突然病攣と右不全片麻痺を発症し緊急入 院となった.

入院時現症: 体重 $10.6 \mathrm{~kg}$, 身長 $85.0 \mathrm{~cm}$, 心拍数 $94 /$ 分, 血圧 $112 / 62 \mathrm{mmHg}$, 呼吸数 36/分, 経皮的酸素飽和 度 $99 \%$, 体温 $36.7^{\circ} \mathrm{C}$ であった。啼泣するも，右上下 肢の動きに乏しく，右口角流涎とともに左上下肢に間 代性痓攣が見られた。

入院後経過：頭部 MRIにて左中大脳動脈領域の血流 途絶と同領域の脳梗塞を認めた。 心エコーでは左室 隔壁で隔てられた左室心尖部の動きは良好であり血 栓を認めなかった（Fig. 1A*)。脳梗塞に対する治療 経過中, 入院 10 日目の心エコーで左室心尖腔に $11 \times$ $10 \mathrm{~mm}$ 大の血栓形成, 心尖腔の機能低下と主腔との 交通狭小化が見られた（Fig. 1B*)。これらの血栓飛 散による臟器梗塞, および機能低下による血行破綻を 回避する目的で緊急手術を行った。

手術所見および術後経過：胸骨正中切開，上行大動脈 送血, 上下静脈脱血にて人工心肺を確立, 大動脈遮 断, 血液心筋保護液にて心停止とし, 左室心尖部を左 前下行枝に平行に $20 \mathrm{~mm}$ 切開して左室副腔に到達し た. 多数の白色線維性索状物に覆われた副腔の奥に暗 赤色の血栓塊を認め（Fig. 2A），これを摘出した（Fig. 2B). 主腔と連絡する slit 状の交通口が心室中隔に隣 接してみられた。僧帽弁乳頭筋が付着する隔壁部分を
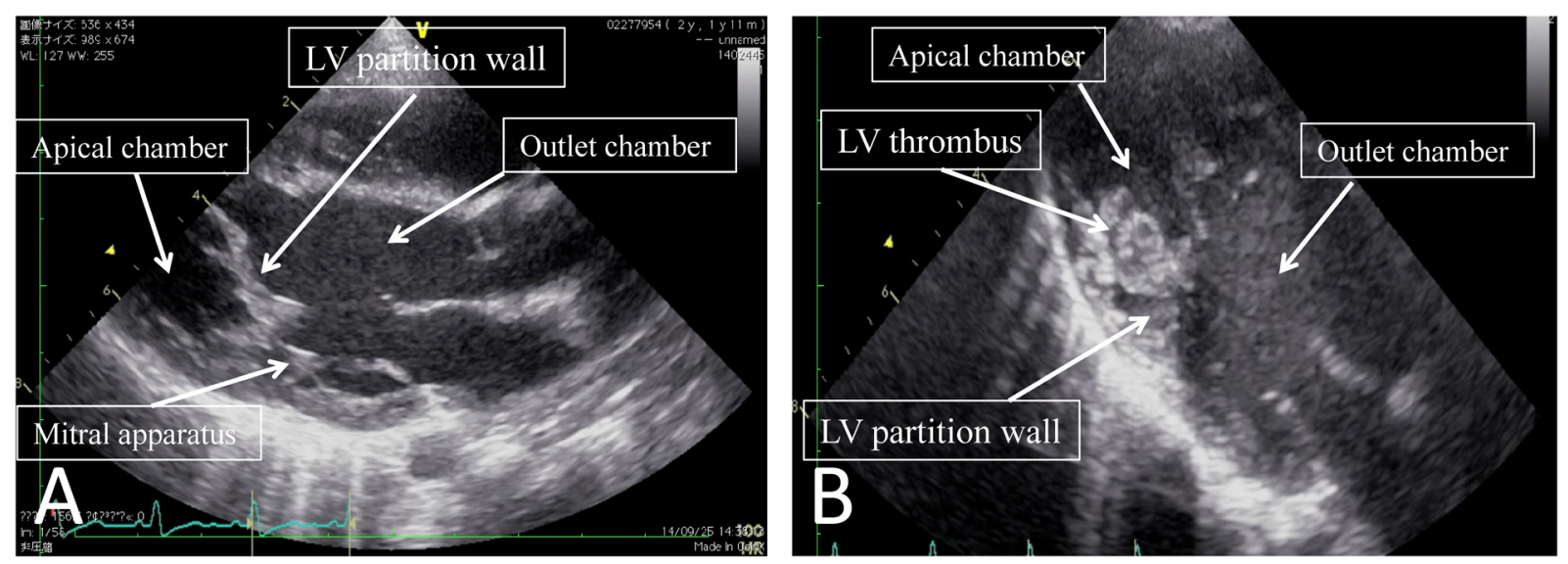

Fig. 1 Preoperative echocardiography

A: At admission. B: 10 days after admission.

*電子版にて動画を配信している. 

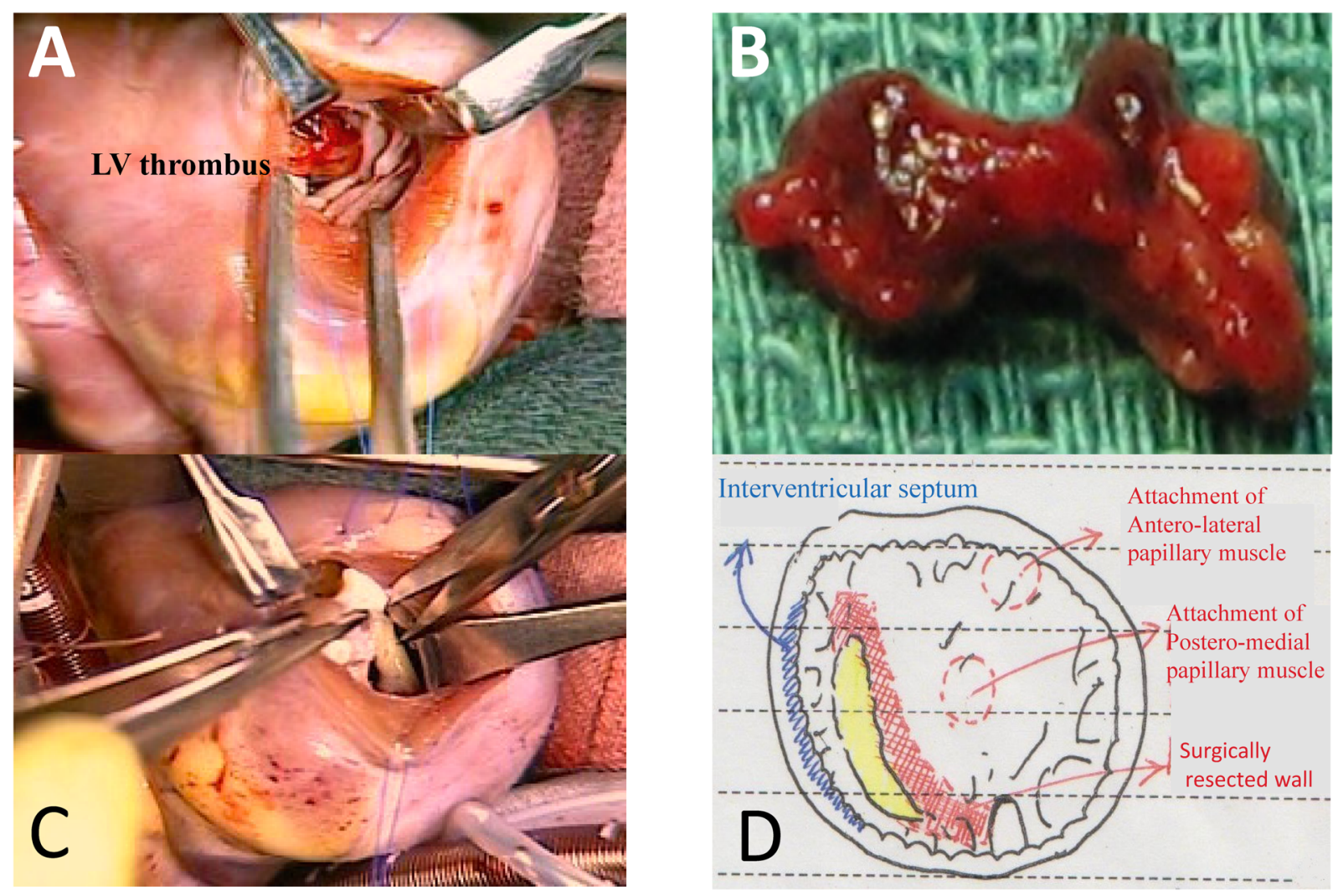

Fig. 2 Operative findings and schema

A: Left ventriculotomy at the apex. B: Extracted thrombus. C: Resection of the partition wall. D: Partition wall (courtesy of Dr. Koji Nomura).

温存しながら，主腔-副腔交通口を可及的に拡大した

(Fig. 2C, D).

第 1 病日に抜管した. 左室副腔機能は速やかに改善 し，神経学的所見の悪化もなく，第 27 病日に軽快退院 した. 術後9ケ月時の心エコー上, 左室副腔機能は良好 に維持され血栓や僧帽弁逆流を認めていない（Fig. 3*). 自発運動に左右差を認めず歩行可能となっている.

\section{病理所見}

隔壁内部は正常心筋組織が主体で, 表層は膠原線維 に覆われ，一部に弾性線維を認めた。炎症所見は見ら れず，「正常心内中隔組織」に矛盾しない所見であっ た (Fig. 4).

\section{考察}

左室二腔症の成因として心筋症からの二次的変化

*電子版にて動画を配信している.
による瘤化 ${ }^{3,4)}$ や，心内膜線維弾性化による収縮能低 下, 拡張から二腔化を呈する例 ${ }^{5)}$, さらには左室心筋 の先天的な構築異常から発生する憩室化などが報告さ れている.これらは先天的素因であるがゆえに胎生 期 ${ }^{6)}$, あるいは生後すぐに ${ }^{7)}$ 異常を指摘される例も あるが，成人期になって発見された報告もあり ${ }^{8)}$ そ の発症時期は様々である。 また，症状や重症度におい ても心筋梗塞，致死的不整脈，心室破裂など成人期に 発症する左室瘤，左室悡室は劇症型であるのに対し て ${ }^{9)}$, 小巟期に発症する二腔症では心雑音や体重増加 不良などの緩慢な症状で発症する例が散見され ${ }^{3,7)}$, その臨床像も多岐にわたる。本症例では乳児期を過ぎ て初めて左室内隔壁を指摘され，その後急速に血栓形 成，機能低下に至ったという点で過去に例を見ない 経過を辿った。胎生期や生直後に形態的異常を認めな かったという点で先天的構築異常に起因する惒室や瘤 化は考えにくい，本症例の隔壁組織所見を見ると，膠 原線維に覆われた正常心筋組織により構築されていた ことから心筋症や緻密化障害などによる形態変化では ないことを示唆している. 

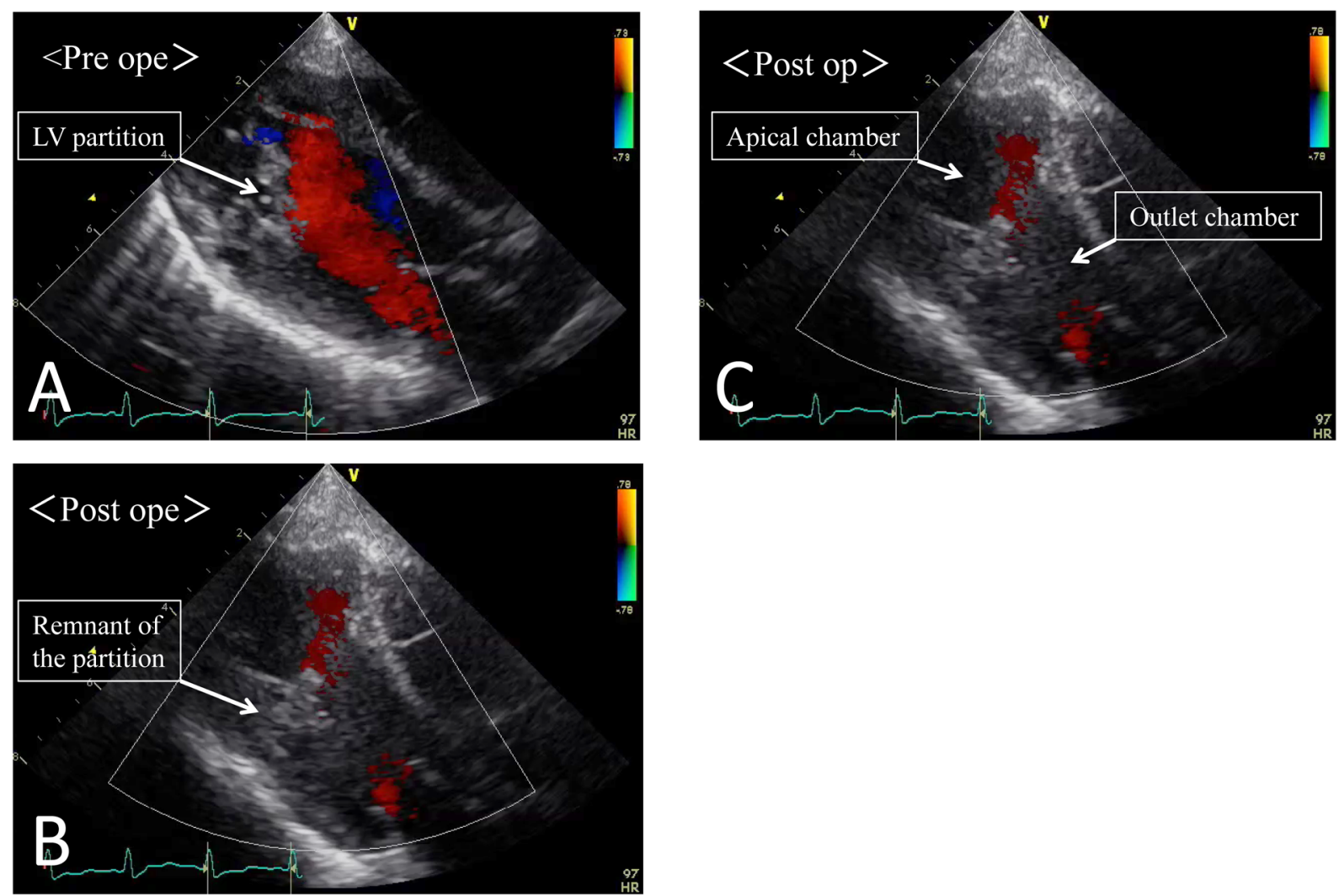

Fig. 3 Perioperative echocardiography

A: Preoperative echo showed a narrow communication between the two chambers of the left ventricle. B: Echocardiography 1 week after surgery. C: Echocardiography 9 months after surgery showed a wide communication similar to that seen at immediately after surgery.

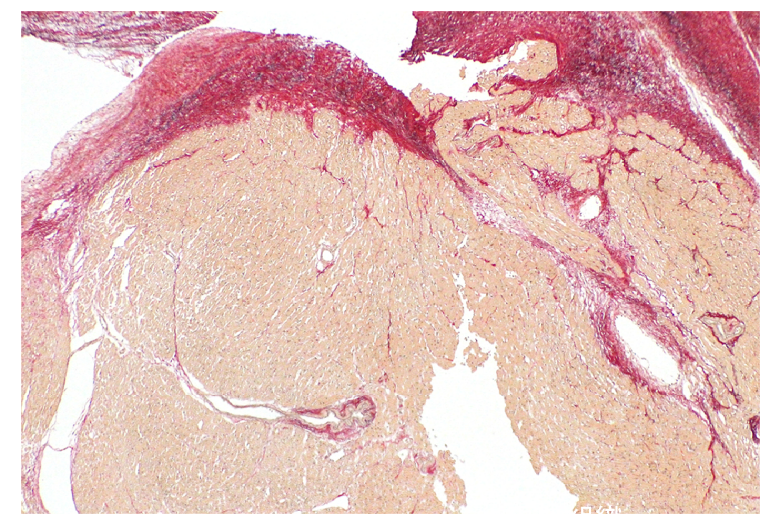

Fig. 4 Histological findings of the resected partition wall

The partition wall consisted of the myocardium covered with collagen fiber, which was consistent with the normal cardiac septum (Elastica van Gieson stain, original magnification, $\times 40$ ).

術前シンチグフィーにて左室心筋の血流低下を指摘 されていたが, 後天性虚血変化では通常 outpouching 形態を呈することが多く, 形態的に合致しない. 隔壁
には僧帽弁乳頭筋が連続しており，その組織像が乳頭 筋の発生由来である左室心筋組織 ${ }^{10 ）}$ と相違ないこと から，一連の隔壁形成過程が何らかの乳頭筋，左室心 筋の構造変化に関与しているものと考えられる. 左室 副腔壁組織が肥厚した心筋と膠原線維から成るという 組織学的に近似した報告例がある ${ }^{11)} も の の 二$ 二空化成 因については言及されておらず，隔壁の形成過程を正 確に把握することは極めて困難である.

本疾患に対する外科治療は様々な術式が報告されて いるが，副腔を犠牲にする ${ }^{7,12)}$ か，温存する ${ }^{13)}$ かに 大別される．前者として Dor 手術や副腔閉鎖術が相 当し，左室副腔を犠牲にしても主腔のみで十分な心拍 出量を維持できること, 僧帽弁機能に影響のないこと などが適応基準となり，概ね左室外に向かって拡張す る馝室や瘤に対して有効な術式である，一方，副腔を 温存する術式には隔壁切除術があるが, その切除範囲 は僧帽弁下組織の形態による. 本症例はカテーテル検 査にて左室全体の容積が $98 \% \mathrm{~N}$ と大きくなく，その 中で副腔が左室全体の半分を占めることから, 主腔の みでは十分な心拍出量を維持できない可能性が極めて 
高く, Dor 手術や副腔閉鎖術を適応から除外した。 本例のように outpouching でない副腔形態に対する 隔壁の完全切除は, Dogan ら ${ }^{13 ）}$ により報告されてい る.ただし，13歳の年長児例であり，僧帽弁置換術 の併施が可能であった. 本症例においても，隔壁と 2 つの僧帽弁乳頭筋が連続していることから完全切除の 際には人工弁置換が必須となる. しかし幼児期僧帽弁 置換後には血栓, 出血, 機能不全などのリスク ${ }^{14 ）}$ が あり，今回は僧帽弁機能を温存することを前提に隔壁 の部分切除にとどめた. 将来的に隔壁造成による再手 術介入が必要なった場合でも，成長に伴って至適サイ ズの人工弁置換が可能になろう。術後短期的には血栓 再発を認めず副腔機能の改善が得られているが，引き 続き主腔-副腔交通の再狭窄や血栓再燃, 副腔機能に は細心の注意を要する。

\section{終わりに}

左室二腔症の 2 歳児に対して左室内隔壁部分切除術 を施行した。発生成因は不明であるが，非常に稀な発 症経過を辿った。術後はワーファリンによる抗凝固管 理を継続して術後 1 年の現在まで，特に合併症なく経 過している．隔壁の再形成，血栓再燃，副腔機能低下 など，今後も厳重な経過観察が必要である。

\section{引用文献}

1) Malakan RE, Awad S, Hijazi ZM: Congenital left ventricular outpouchings: A systematic review of 839 cases and introduction of a novel classification after two centuries. Congenit Heart Dis 2014; 9: 498-511

2) Novo G, Dendramis G, Marrone G, et al: Left ventricu- lar noncompaction presenting like a double-chambered left ventricle. J Cardiovasc Med (Hagerstown) 2015; 16: 522-524

3) Paronetto F, Strauss L: Aneurysm of the left ventricle due to congenital muscle defect in an infant. Am J Cardiol 1963; 12: 721-729

4) Alday LE, Moreyra E, Quiroga C, et al: Cardiomyopathy complicated by left ventricular aneurysms in children. $\mathrm{Br}$ Heart J 1976; 38: 162-166

5) Gerlis LM, Partridge JB, Fiddler GI, et al: Two chambered left ventricle. Three new varieties. Br Heart J 1981; 46 278-284

6) Bernasconi A, Delezoide AL, Menez F, et al: Prenatal rupture of a left ventricular diverticulum: A case report and review of the literature. Prenat Diagn 2004; 24: 504-507

7) Kay PH, Rigby M, Mulholland HC: Congenital double chambered left ventricle treated by exclusion of accessory chamber. Br Heart J 1983; 49: 195-198

8) Studer M, Zuber M, Jamshidi P, et al: Thromboembolic acute myocardial infarction in a congenital double chambered left ventricle. Indian Heart J 2011; 63: 289-290

9) Ohlow MA, von Korn H, Lauer B: Characteristics and outcome of congenital left ventricular aneurysm and diverticulum: Analysis of 809 cases published since 1816 . Int J Cardiol 2015; 185: 34-45

10) Seguela PE, Houyel L, Acar P: Congenital malformations of the mitral valve. Arch Cardiovasc Dis 2011; 104: 465479

11) Ihoriya $F$, Imataki $\mathrm{K}$, Tani $\mathrm{H}$, et al: A case of two-chambered left ventricle with echoes of an abnormal floating mass. J Cardiogr 1984; 14: 615-622

12) Rastan AJ, Walther T, Daehnert I, et al: Left ventricular diverticulum repair in a newborn. Thorac Cardiovasc Surg 2007; 55: 61-64

13) Dogan OF, Alehan D, Duman U: Successful surgical management of a double-chambered left ventricle in a 13-year-old girl: A report of a rare case. Heart Surg Forum 2004; 7: E198-E200

14) Brown JW, Fiore AC, Ruzmetov M, et al: Evolution of mitral valve replacement in children: A 40-year experience. Ann Thorac Surg 2012; 93: 626-633 